OPEN ACCESS

Edited by:

Meghit Boumediene Khaled, Université Djillali Liabes, Algeria

Reviewed by:

Mustapha Diaf,

Université Djillali Liabes, Algeria Slimane Belbraouet,

Université de Moncton, Canada

*Correspondence:

Owais Khawaja oajaz@yahoo.com

Specialty section:

This article was submitted

to Clinical Nutrition,

a section of the journal

Frontiers in Nutrition

Received: 01 February 2017 Accepted: 13 March 2017

Published: 27 March 2017

Citation:

Khawaja O, Singh $H$, Luni $F$, Kabour A, Ali SS, Taleb M, Ahmed H, Gaziano JM and Djoussé L (2017)

Egg Consumption and Incidence of Heart Failure: A Meta-Analysis of

Prospective Cohort Studies.

Front. Nutr. 4:10.

doi: 10.3389/fnut.2017.00010

\section{Egg Consumption and Incidence of Heart Failure: A Meta-Analysis of Prospective Cohort Studies}

\author{
Owais Khawaja ${ }^{1 *}$, Hemindermeet Singh ${ }^{1}$, Faraz Luni', Ameer Kabour', Syed S. Ali', \\ Mohammed Taleb', Hafeezuddin Ahmed", John Michael Gaziano ${ }^{2,3,4,5}$ and Luc Djoussé2,4,5 \\ ${ }^{1}$ Department of Cardiology, Mercy St. Vincent Medical Center, Toledo, OH, USA, ${ }^{2}$ Division of Aging, Brigham and Women's \\ Hospital, Harvard Medical School, Boston, MA, USA, ${ }^{3}$ Massachusetts Veterans Epidemiology and Research Information \\ Center (MAVERIC), Boston Veterans Affairs Healthcare System, Boston, MA, USA, ${ }^{4}$ Preventive Medicine, Brigham and \\ Women's Hospital, Harvard Medical School, Boston, MA, USA, ${ }^{5}$ Geriatric Research, Education, and Clinical Center \\ (GRECC), Boston Veterans Affairs Healthcare System, Boston, MA, USA
}

Introduction: Heart failure (HF) remains a major health problem affecting 5.7 million adults in USA. Data on the association of egg consumption with incident HF have been inconsistent. We, therefore, conducted this meta-analysis of prospective cohort studies to assess the relation of egg consumption with incident HF in the general population.

Methods: Using extensive online search, we conducted a meta-analysis of new onset HF following exposure to egg consumption. A random effects model was used and between studies heterogeneity was estimated with $r^{2}$. Publication bias was assessed graphically using a funnel plot. All analyses were performed with Comprehensive MetaAnalysis (version 2.2.064).

Results: We identified four prospective cohorts for a total of 105,999 subjects and 5,059 cases of new onset HF. When comparing the highest ( $\geq 1 /$ day) to the lowest category of egg consumption, pooled relative risk of HF was 1.25 (95\% confidence interval $=1.12-1.39 ; p=0.00)$. There was no evidence for heterogeneity $\left(l^{2}=0 \%\right)$ nor publication bias. On sensitivity analysis, stratification by gender differences, follow-up duration, and region where study was conducted did not alter the main conclusion.

Conclusion: Our meta-analysis suggests an elevated risk of incident HF with frequent egg consumption.

Keywords: eggs, heart failure, nutrition, epidemiology, diet

\section{INTRODUCTION}

Heart failure (HF) is highly prevalent in clinical practice affecting Americans $\geq 20$ years of age (1). The incidence of HF approaches 10 per 1,000 population after 65 years of age and remains high around $20 \%$ at 80 years of age (2). Although, survival after HF diagnosis has improved over the years, death rate continues to remain high at $\sim 50 \%$ within 5 years (3). HF has a major economic impact with total projected cost by year 2030 being $\$ 69.7$ billion, an increase from estimated $\$ 30.7$ billion for the year 2012 (4). 
The traditional risk factors for HF include coronary heart disease (CHD), hypertension (HTN), diabetes mellitus (DM), cigarette smoking, obesity, dietary sodium intake, and valvular heart disease (5). Overall, CHD has been shown to account for about $62 \%$ (68\% in men and $56 \%$ in women) of all HF cases. Eggs are an important source of phosphatidylcholine in human diet (6). In addition, they are an important source of various beneficial minerals and nutrients like vitamin A, vitamin $\mathrm{D}$, calcium, xanthophyll, and folate (7). Dietary choline has been associated with increased trimethylamine-N-oxide (TMAO) production, which in turn may be an important predictor of CHD (8).

Although data on the association of egg consumption with CHD or stroke are inconsistent in the general population (9-11), an increased risk for $\mathrm{CHD}$, stroke, and mortality has been noted among those with DM (12-14). In a recent meta-analysis, frequent egg consumption was also shown to be associated with incident DM (15). However, data on the association of egg consumption with incident HF have been conflicting (16-18).

Identification of simple and inexpensive yet effective strategies to help prevent incident HF can be of paramount importance. This can help reduce not only the overall morbidity and mortality as well as the healthcare costs related to HF. We, therefore, conducted this meta-analysis of population bases prospective cohort studies to examine the association of egg consumption with incident HF in humans.

\section{MATERIALS AND METHODS}

\section{Search Strategy}

We conducted a search in PubMed, Cochrane library, and Google Scholar up to May 2016 for studies that reported the association of egg consumption with incident HF. We used the following keywords for our search: eggs, nutrition, and HF. The search was performed for studies in English language and was limited to human subjects. When an abstract from a meeting and a full article referred to the same report, only the full report was included in the analysis. In case of multiple reports from the same study, we used the most complete and/or recently reported data. References of the retrieved articles and review articles were also manually screened for eligible studies.

\section{Inclusion and Exclusion Criteria}

We included population-based prospective cohort studies reporting on the association of egg consumption and incident HF. Only the studies comparing event rates between two or more groups with complete information available were included.

\section{Data Extraction}

Data for each study were abstracted by an investigator (Owais Khawaja) and were confirmed by a second investigator (Hemindermeet Singh). Each author used the same template to extract first author's name, year of publication, country where study was conducted, population characteristics (mean age and range, gender proportion, number of DM, sample size), study design (cohort vs case-control), mean follow-up, categories of egg consumption, person-time of follow-up within each category of egg consumption for cohort, statistical method used to obtain effect size (logistic regression vs Cox proportional hazard model), covariates adjusted for, and relative risk (RR) with $95 \%$ confidence interval (CI).

Each author used the same template to extract first author's name, year of publication, region of study, population characteristics, mean follow-up, categories of egg consumption, statistical method used (Cox proportional hazard model), covariates adjusted for (age, education, physical activity, body mass index, smoking, alcohol consumption, history of DM, atrial fibrillation, HTN, etc.), and RR with 95\% CI. In case of a disagreement, the discrepancies were resolved by group discussion between the reviewers.

\section{Statistical Analysis}

The meta-analysis was performed by computing RR using random effects model. RR for incident HF was calculated along with the 95\% CIs. Between studies, heterogeneity was analyzed by means of $I^{2}$, which describes the percentage of the variability in effect estimate across studies that is due to heterogeneity rather than sampling error (chance). Publication bias was assessed graphically using a funnel plot. We also conducted sensitivity analysis to evaluate the impact of excluding studies with (a) only men/ women, (b) $<20$ years follow-up duration, and (c) US/Non-US

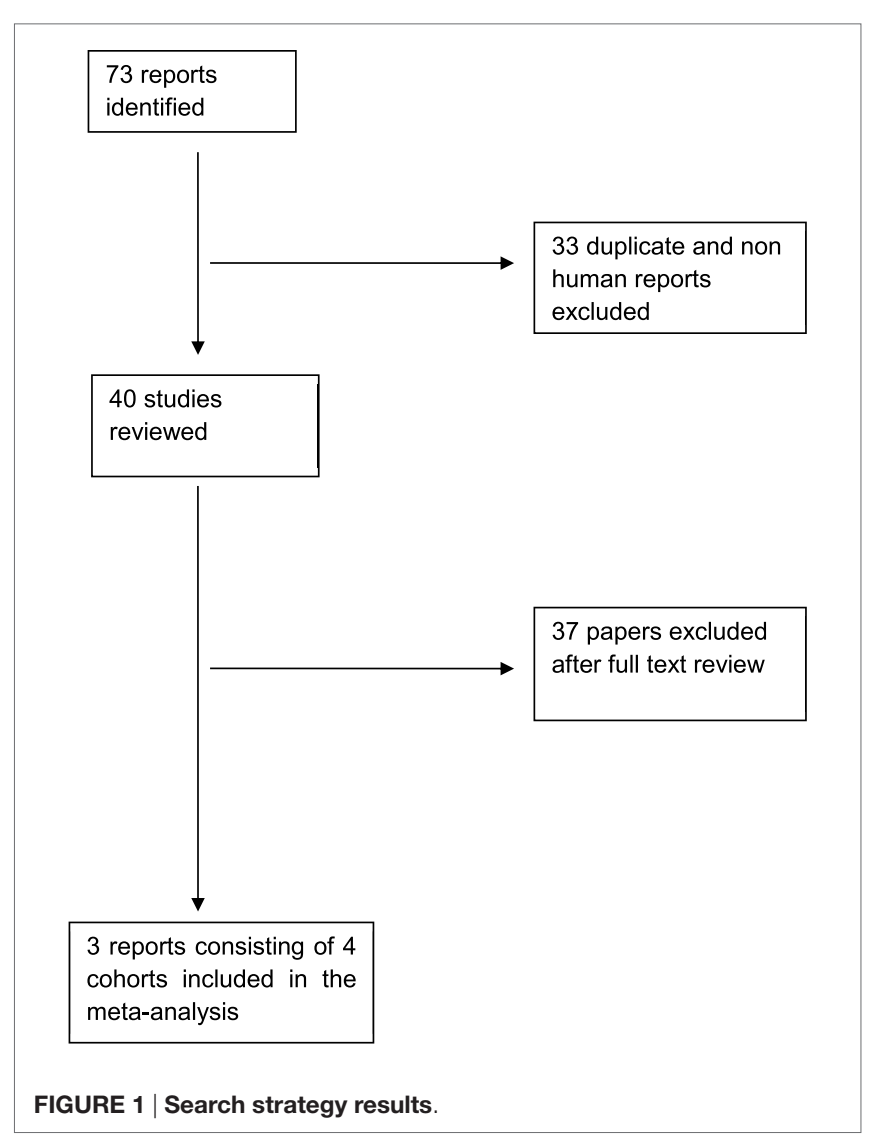


studies on the pooled RR. All analyses were performed with Comprehensive Meta-Analysis (version 2.2.064).

\section{RESULTS}

Overall, we found 73 reports on the primary search and excluded 33 studies because of duplication or non-human subjects. From the remaining 40 reports, we included 3 reports consisting of four cohorts after full text review. All included studies were population-based prospective cohort studies. Figure 1 summarizes the results of literature search along with excluded studies. Basic characteristics of these studies are shown in Table 1.

Three population-based prospective cohort studies with four distinct cohorts were included in this meta-analysis [Djousse (men) (16), Nettleton (men/women) (17), Larsson (men) (18), and Larsson (women) (18)]. For our analysis, we only included those in the highest and the lowest category of egg consumption from each of these cohort studies. Overall, these prospective cohort studies had a total of 106,989 participants with 49,931 $(47 \%)$ in the lowest and 3,093 (3\%) in the highest category ( $\geq 1 /$ day) of egg consumption. Larsson (men) (18) had the most number of participants, while Nettleton (men/women) (17) had the least number of participants. Overall, there were 2,764 cases of incident HF. On comparing the highest to the lowest category of egg consumption, the pooled RR for incident HF was 1.25 (95\% CI: 1.12, 1.39; Figure 2). There was no evidence for heterogeneity $\left(I^{2}=0 \%\right)$.

Sensitivity analysis (stratification by excluding studies with men/women, $<20$ years of follow-up duration, US/Non-US studies) did not alter the main conclusion (Table 2). There was no evidence of publication bias on funnel plot analysis (Figure 3) as supported by the Egger's test $(p=0.68)$.

\section{DISCUSSION}

Based on the findings of this meta-analysis, frequent egg consumption was associated with a higher risk of incident HF. In

TABLE 1 | Baseline characteristics of study included in meta-analysis.

\begin{tabular}{|c|c|c|c|c|c|c|c|c|}
\hline $\begin{array}{l}\text { First author, } \\
\text { publication year, } \\
\text { country }\end{array}$ & Study name & $\begin{array}{l}\text { Study } \\
\text { size }\end{array}$ & $\begin{array}{l}\text { Age } \\
\text { range } \\
\text { (years) }\end{array}$ & $\begin{array}{l}\text { Follow- } \\
\text { up period } \\
\text { (years) }\end{array}$ & $\begin{array}{l}\text { Dietary } \\
\text { assessment }\end{array}$ & Exposure categories & $\begin{array}{l}\text { No of subjects } \\
\text { (lowest vs } \\
\text { highest } \\
\text { category) }\end{array}$ & $\begin{array}{l}\text { No of cases } \\
\text { (lowest vs } \\
\text { highest } \\
\text { category) }\end{array}$ \\
\hline $\begin{array}{l}\text { Djousse (men), } \\
\text { 2008, USA }\end{array}$ & $\begin{array}{l}\text { Physician's health } \\
\text { study }\end{array}$ & 21,275 & $53-57$ & 20.4 & $\begin{array}{l}\text { Semi } \\
\text { quantitative FFQ }\end{array}$ & $\begin{array}{l}\text { Six groups: <1/week, 1/week, 2-4/ } \\
\text { week, 5-6/week, 1/day, and 2+/day }\end{array}$ & 4,527 vs 264 & 206 vs 25 \\
\hline $\begin{array}{l}\text { Nettleton (men/ } \\
\text { women), 2008, USA }\end{array}$ & $\begin{array}{l}\text { Atherosclerosis } \\
\text { risk in } \\
\text { communities }\end{array}$ & 15,143 & $54-57$ & 13.3 & $\begin{array}{l}\text { Semi } \\
\text { quantitative FFQ }\end{array}$ & $\begin{array}{l}\text { Nine groups: } \leq 1 / \text { month to } \geq 6 / \text { day. } \\
\text { Analyzed as per } 1 \text { SD difference in } \\
\text { dietary pattern score or per } 1 \text { daily } \\
\text { serving difference in food group } \\
\text { intake }\end{array}$ & 13,013 vs 1,140 & $\begin{array}{l}1,140 \text { total } \\
\text { (differential data } \\
\text { not available) }\end{array}$ \\
\hline $\begin{array}{l}\text { Larson (men), 2015, } \\
\text { Sweden }\end{array}$ & $\begin{array}{l}\text { Cohort of } \\
\text { Swedish men }\end{array}$ & 37,766 & 59-61 & 13.0 & $\begin{array}{l}\text { Semi } \\
\text { quantitative FFQ }\end{array}$ & $\begin{array}{l}\text { Four groups: 0-3/month, 1-2/week, } \\
3-6 / \text { week, and 1+/day }\end{array}$ & 17,635 vs 1,007 & 724 vs 72 \\
\hline $\begin{array}{l}\text { Larson (women), } \\
\text { 2015, Sweden }\end{array}$ & $\begin{array}{l}\text { Swedish } \\
\text { mammography } \\
\text { cohort }\end{array}$ & 32,805 & $61-63$ & 13.0 & $\begin{array}{l}\text { Semi } \\
\text { quantitative FFQ }\end{array}$ & $\begin{array}{l}\text { Four groups: 0-3/month, 1-2/week, } \\
3-6 / \text { week, and 1+/day }\end{array}$ & 14,756 vs 682 & 560 vs 37 \\
\hline
\end{tabular}

FFQ, food frequency questionnaire.

\section{Meta Analysis}

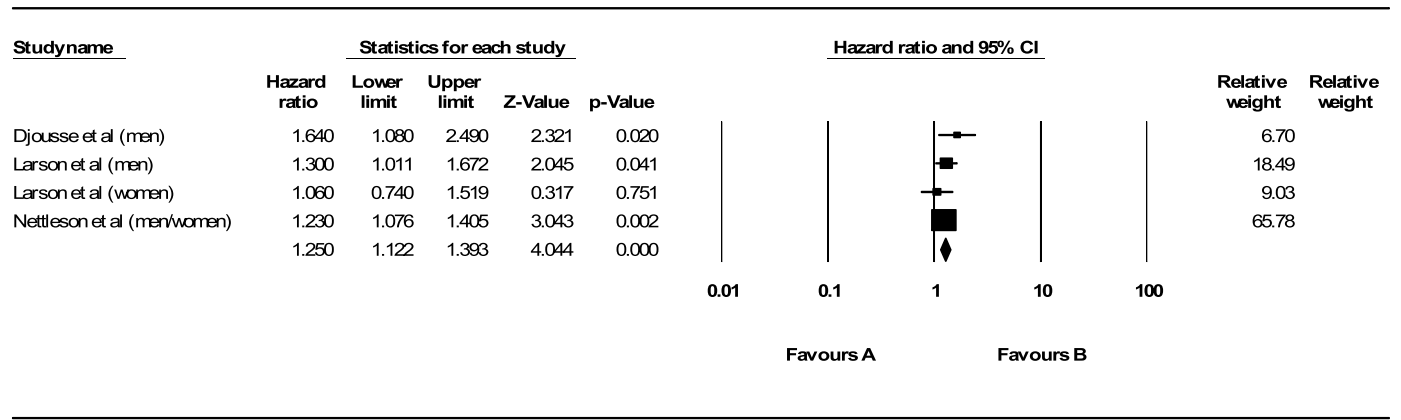

Meta Analysis

FIGURE 2 | Pooled relative risk for egg consumption and incident heart failure across prospective cohort studies 
TABLE 2 | Sensitivity analysis.

\begin{tabular}{|c|c|c|}
\hline Included studies & $\begin{array}{l}\text { Relative risk ( } 95 \% \\
\text { confidence interval) }\end{array}$ & $p$ Value \\
\hline $\begin{array}{l}\text { Excluding studies with women vs all } \\
\text { included prospective cohort studies }\end{array}$ & $\begin{array}{c}1.38(1.12,1.71) \text { vs } 1.25 \\
(1.12,1.39)\end{array}$ & 0.414 \\
\hline $\begin{array}{l}\text { Excluding studies with men vs all included } \\
\text { prospective cohort studies }\end{array}$ & $\begin{array}{c}1.06(0.74,1.52) \text { vs } 1.25 \\
(1.12,1.39)\end{array}$ & 0.389 \\
\hline $\begin{array}{l}\text { Excluding studies with }<20 \text { years of } \\
\text { follow-up vs all included prospective cohort } \\
\text { studies }\end{array}$ & $\begin{array}{c}1.64(1.08,2.49) \text { vs } 1.25 \\
(1.12,1.39)\end{array}$ & 0.217 \\
\hline $\begin{array}{l}\text { Excluding non-US studies vs all included } \\
\text { prospective cohort studies }\end{array}$ & $\begin{array}{c}1.32(1.04,1.69) \text { vs } 1.25 \\
(1.12,1.39)\end{array}$ & 0.687 \\
\hline $\begin{array}{l}\text { Excluding US studies vs all included } \\
\text { prospective cohort studies }\end{array}$ & $\begin{array}{c}1.22(0.99,1.49) \text { vs } 1.25 \\
(1.12,1.39)\end{array}$ & 0.205 \\
\hline
\end{tabular}

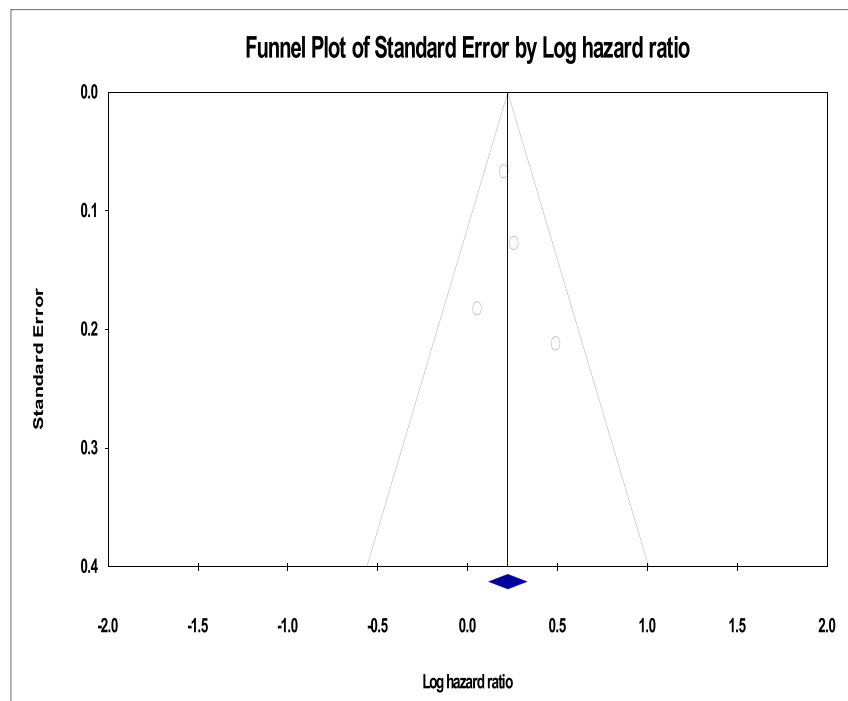

FIGURE 3 | Funnel plot for pooled analysis for cohort studies. There is no evidence of publication bias seen.

addition, results of sensitivity analysis did not alter the main conclusion.

Data from our study are somewhat consistent with prior studies. Longitudinal data from various population-based studies have shown a steady increase in HF risk secondary to $\operatorname{CHD}$ and $\mathrm{DM}(5,19,20)$. Data on the association of egg consumption with CVD (cardiovascular disease) outcomes have been inconsistent. Shin et al. (12) did not demonstrate that elevated risk for $\mathrm{CHD}$, stroke, or mortality with egg consumption. However, those who ate $1+$ egg per day were $42 \%$ more likely to develop DM and among those with DM frequent egg consumption was associated with increased CVD comorbidity (HR: 1.69; 95\% CI: 1.09-2.62). Similarly, Rong et al. (10) in their analysis demonstrated a higher risk of CHD (RR: 1.54; 95\% CI: 1.14-2.09) among people with diabetes. Recently, Djousse et al. (15) in a meta-analysis of prospective cohort studies demonstrated a modestly positive association between frequent egg consumption and incident DM. This was, however, limited to $4+$ eggs/week and mostly restricted to US studies. Our analysis did not reveal regional variation with respect to outcome.

Hypertension has been shown to be a more important cause of $\mathrm{HF}$ in women, while CHD which has been shown to be the more important cause of HF in men (21). Also, HF with preserved left ventricular ejection is the more common type of HF seen in women. However, we did not have enough number of studies or specific information on the type of HF to make any definitive conclusions. This will need to be further explored in additional studies.

Eggs consumption has been associated with increased production of TMAO (8). Wang et al. (22) in an animal study demonstrated TMAO dietary supplementation of mice to be associated with upregulation of multiple macrophage scavenger receptors linked to atherosclerosis. Tang et al. (23) in their study demonstrated elevated TMAO levels to be associated with an increased risk of major adverse cardiovascular events even after adjustment for traditional risk factors $(p<0.001)$. Senthong et al. (24) in their prospective cohort study of 353 stable CHD patients demonstrated fasting plasma TMAO levels to be an independent predictor of a high atherosclerotic burden. Mafune et al. (25) in their cross-sectional study of 227 patients who underwent cardiovascular surgery demonstrated a significantly increased number of infarcted coronary arteries among those with elevated TMAO levels.

Trøseid et al. (26) in their prospective analysis of 155 patients with chronic HF demonstrated that elevated TMAO levels among patients with advanced HF symptoms and those with ischemic etiology in addition to reduced transplant-free survival over a 5.2-year follow-up (hazard ratio 2.24 , 95\% CI 1.28-3.92, $p=0.005)$. However, the association of egg consumption with CHD has been inconsistent in general population (9-11), while an increased risk for $\mathrm{CHD}$ has been observed among diabetics (12-14). This raises the concern for confounding by dietary patterns. However, due to inadequate available information on relevant dietary factors or dietary patterns in specific subgroups we were unable to further elucidate this issue. Therefore, further studies accounting for comprehensive dietary patterns in addition to consumption of eggs will be needed to explore the underlying biological mechanisms.

Our systematic review has several strengths. All studies included were prospective in nature. The large sample size and prolonged duration of follow-up improved the statistical power to detect smaller effect size. Outcome in the current study was validly ascertained, thereby minimizing misclassification of outcome. On the other hand, our analysis has some possible limitations. Owing to the observational nature of studies, one cannot entirely exclude unmeasured or residual confounding. Also, self-reported egg consumption using FFQ might have introduced exposure misclassification. However, since FFQ was obtained prior to incident HF, such misclassification is more likely to be non-differential. We were unable to account for the various cooking methods of eggs and additives which could be another variation factor. 
We could not isolate egg consumption from food products containing eggs, which can be a potential bias. We were unable to further look into the composition of eggs and their nutritional quality, which may vary according to the species and the breed of the laying hen. Moreover, we were not able to further classify the type of HF.

Overall, this meta-analysis of population-based prospective cohort studies suggests an elevated risk of HF with frequent egg consumption in humans. Further studies are warranted to explore the underlying biological mechanisms.

\section{REFERENCES}

1. Writing Group Members, Mozaffarian D, Benjamin EJ, Go AS, Arnett DK, Blaha MJ, et al. Heart disease and stroke statistics-2016 update: a report from the American Heart Association. Circulation (2016) 133:e38-60. doi:10.1161/ CIR.0000000000000350

2. Lloyd-Jones DM, Larson MG, Leip EP, Beiser A, D’Agostino RB, Kannel $\mathrm{WB}$, et al. Lifetime risk for developing congestive heart failure: the Framingham Heart Study. Circulation (2002) 106:3068-72. doi:10.1161/01. CIR.0000039105.49749.6F

3. Roger VL, Weston SA, Redfield MM, Hellermann-Homan JP, Killian J, Yawn BP, et al. Trends in heart failure incidence and survival in a community-based population. JAMA (2004) 292:344-50. doi:10.1001/jama.292.3.344

4. Heidenreich PA, Albert NM, Allen LA, Bluemke DA, Butler J, Fonarow GC, et al. Forecasting the impact of heart failure in the United States: a policy statement from the American Heart Association. Circ Heart Fail (2013) 6:606-19. doi:10.1161/HHF.0b013e318291329a

5. He J, Ogden LG, Bazzano LA, Vupputuri S, Loria C, Whelton PK. Risk factors for congestive heart failure in US men and women: NHANES I epidemiologic follow-up study. Arch Intern Med (2001) 161:996-1002.

6. U.S. Department of Agriculture, Agricultural Research Service. USDA National Nutrient Database for Standard Reference, Release 26. Beltsville, MD: BARC-West (2013). Available from: https://www.ars.usda.gov/ ARSUserFiles/80400525/Data/Choline/Choln02.pdf

7. U.S. Department of Agriculture, Agricultural Research Service. USDA National Nutrient Database for Standard Reference, Release 28. Beltsville, MD: BARC-West (2015). Available from: https://www.ars.usda.gov/ ARSUserFiles/80400525/Data/SR/SR28/reports/sr28fg01.pdf

8. Miller CA, Corbin KD, da Costa KA, Zhang S, Zhao X, Galanko JA, et al. Effect of egg ingestion on trimethylamine- $\mathrm{N}$-oxide production in humans: a randomized, controlled, dose-response study. Am J Clin Nutr (2014) 100:778-86. doi:10.3945/ajen.114.087692

9. Djousse L, Gaziano JM. Dietary cholesterol and coronary artery disease: a systematic review. Curr Atheroscler Rep (2009) 11:418-22. doi:10.1007/ s11883-009-0063-1

10. Rong Y, Chen L, Zhu T, Song Y, Yu M, Shan Z, et al. Egg consumption and risk of coronary heart disease and stroke: dose-response meta-analysis of prospective cohort studies. BMJ (2013) 346:e8539. doi:10.1136/bmj.e8539

11. Djousse L. Relation of eggs with incident cardiovascular disease and diabetes: friends or foes? Atherosclerosis (2013) 229:507-8. doi:10.1016/j. atherosclerosis.2013.05.003

12. Shin JY, Xun P, Nakamura Y, He K. Egg consumption in relation to risk of cardiovascular disease and diabetes: a systematic review and meta-analysis. Am J Clin Nutr (2013) 98:146-59. doi:10.3945/ajcn.112.051318

13. Tran NL, Barraj LM, Heilman JM, Scrafford CG. Egg consumption and cardiovascular disease among diabetic individuals: a systematic review of the literature. Diabetes Metab Syndr Obes (2014) 7:121-37. doi:10.2147/DMSO. S58668

14. Djousse L, Gaziano JM. Egg consumption in relation to cardiovascular disease and mortality: the Physicians' Health Study. Am J Clin Nutr (2008) 87:964-9.

15. Djoussé L, Khawaja O, Gaziano JM. Egg consumption and risk of type 2 diabetes: a meta-analysis of prospective studies. Am J Clin Nutr (2016) 103:474-80. doi:10.3945/ajen.115.119933

\section{AUTHOR CONTRIBUTIONS}

OK came up with the idea. OK and HS did data collection and analysis. OK, HS, FL, and HA wrote initial version. AK, SA, MT, HA, JG, and LD provided critical input.

\section{ACKNOWLEDGMENTS}

Acknowledgment to all contributors who do not meet the criteria for authorship.

16. Djoussé L, Gaziano JM. Egg consumption and risk of heart failure in the Physicians' Health Study. Circulation (2008) 117:512-6. doi:10.1161/ CIRCULATIONAHA.107.734210

17. Nettleton JA, Steffen LM, Loehr LR, Rosamond WD, Folsom AR. Incident heart failure is associated with lower whole-grain intake and greater high-fat dairy and egg intake in the Atherosclerosis Risk in Communities (ARIC) study. JAm Diet Assoc (2008) 108:1881-7. doi:10.1016/j. jada.2008.08.015

18. Larsson SC, Åkesson A, Wolk A. Egg consumption and risk of heart failure, myocardial infarction, and stroke: results from 2 prospective cohorts. Am J Clin Nutr (2015) 102:1007-13. doi:10.3945/ajcn.115.119263

19. McKee PA, Castelli WP, McNamara PM, Kannel WB. The natural history of congestive heart failure: the Framingham study. N Engl J Med (1971) 285:1441-6. doi:10.1056/NEJM197112232852601

20. Gottdiener JS, Arnold AM, Aurigemma GP, Polak JF, Tracy RP, Kitzman DW, et al. Predictors of congestive heart failure in the elderly: the Cardiovascular Health Study. JAm Coll Cardiol (2000) 35:1628-37. doi:10.1016/ S0735-1097(00)00582-9

21. Taylor AL. Heart failure in women. Curr Heart Fail Rep (2015) 12:187-95. doi:10.1007/s11897-015-0252-x

22. Wang Z, Klipfell E, Bennett BJ, Koeth R, Levison BS, Dugar B, et al. Gut flora metabolism of phosphatidylcholine promotes cardiovascular disease. Nature (2011) 472:57-63. doi:10.1038/nature09922

23. Tang WH, Wang Z, Levison BS, Koeth RA, Britt EB, Fu X, et al. Intestinal microbial metabolism of phosphatidylcholine and cardiovascular risk. N Engl J Med (2013) 368:1575-84. doi:10.1056/NEJMoa1 109400

24. Senthong V, Li XS, Hudec T, Coughlin J, Wu Y, Levison B, et al. Plasma trimethylamine $\mathrm{N}$-oxide, a gut microbe-generated phosphatidylcholine metabolite, is associated with atherosclerotic burden. J Am Coll Cardiol (2016) 67:2620-8. doi:10.1016/j.jacc.2016.03.546

25. Mafune A, Iwamoto T, Tsutsumi Y, Nakashima A, Yamamoto I, Yokoyama $\mathrm{K}$, et al. Associations among serum trimethylamine-N-oxide (TMAO) levels, kidney function and infarcted coronary artery number in patients undergoing cardiovascular surgery: a cross-sectional study. Clin Exp Nephrol (2016) 20:731-9. doi:10.1007/s10157-015-1207-y

26. Trøseid M, Ueland T, Hov JR, Svardal A, Gregersen I, Dahl CP, et al. Microbiota-dependent metabolite trimethylamine-N-oxide is associated with disease severity and survival of patients with chronic heart failure. J Intern Med (2015) 277:717-26. doi:10.1111/joim.12328

Conflict of Interest Statement: LD is a recipient of an investigator initiated grant from American Egg Board.

The reviewer MD and handling editor declared their shared affiliation, and the handling editor states that the process nevertheless met the standards of a fair and objective review.

Copyright (c) 2017 Khawaja, Singh, Luni, Kabour, Ali, Taleb, Ahmed, Gaziano and Djoussé. This is an open-access article distributed under the terms of the Creative Commons Attribution License (CC BY). The use, distribution or reproduction in other forums is permitted, provided the original author(s) or licensor are credited and that the original publication in this journal is cited, in accordance with accepted academic practice. No use, distribution or reproduction is permitted which does not comply with these terms. 